\title{
Auditor Switching and Initial Audit Procedures: A Case Study
}

\author{
Erly Satya Graha Putri \\ Department of Accounting \\ Faculty of Economics and Business, Universitas Indonesia \\ Depok, Indonesia \\ ersatp@gmail.com
}

\author{
Robert Porhas Tobing \\ Department of Accounting \\ Faculty of Economics and Business, Universitas Indonesia \\ Depok, Indonesia \\ robert.tobing16@gmail.com
}

\begin{abstract}
This paper discusses the reasons behind auditor or accounting firm switching and studies initial audit procedures. Auditors need to analyze the real reason behind auditor switching in order to make an appropriate decision during the client acceptance stage (an auditee's willingness to share the real reason for auditor switching is questionable). Broadly speaking, there are two types of auditor switching: mandatory and voluntary. Our finding shows that the main driver of voluntary auditor switching for the specific firm studied in this case (referred to with the alias "Superannuation 12") was to improve audit quality. A first-year audit will most likely have a higher risk than a recurring audit so auditors need to add several extended audit procedures as safeguards. These extended audit procedures should be properly implemented in all of the audit stages, except reporting stage. Therefore, the audit period for an initial audit is longer than for a recurring audit. The auditing firm involved in this case (referred to as "AP 111") had some problems when performing initial audit procedures, which led the author to several suggestions for how this could be addressed authorities and the accounting firm itself.
\end{abstract}

Keywords-accounting firm switching; auditor switching; communication with previous auditor; first-year audit; initial audit procedures.

\section{INTRODUCTION}

Professional skepticism is an important characteristic of a capable auditor, an attitude that involves questioning, being alert and on the lookout for any indication of material misstatement, including intentional and unintentional errors [1-7]. An auditor must be skeptical when evaluating information provided by auditee's management, i.e., Those Charged With Governance (TCWG). This includes an auditee's willingness to disclose the reasons for a change in auditor ("auditor switching") [8]. If the auditor knows the reason(s) for the switch it is easier for the auditor to assess the risks of a prospective auditee, one of the determinants in the client acceptance stage.

The existing literature about auditor switching and initial audits is scanty, particularly with respect to studies that focus on Indonesia. There is an undergraduate thesis about initial audits in the Accounting Department, Faculty of Economics and Business, Universitas Indonesia. It is based on auditing standards in that era, i.e., SPAP - Standards Professional Akuntan Publik (refer to U.S. Generally Accepted Auditing Standards). More recently, auditing standards have been revised from SPAP to Standards Audit
(SA), referring to the International Standards on Auditing in place since January 1, 2013 [9].

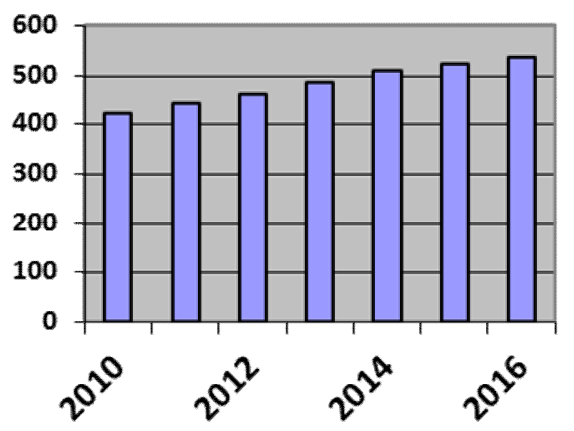

Fig. 1. Growth in the Number of Companies Listed on the Indonesia Stock Exchange

Accounting firms attempting to develop efficient initial audit procedures to evaluate prospective auditee acceptance should consider the following. The head of the Association of Chartered Certified Accountants of Indonesia said that Indonesia still lacks public accountants. The public accountants available in Indonesia are only $5 \%$ of the total needed [10]. Moreover, the number of businesses in need of assurance services from an external auditor continues to grow, according to the growth of listed companies illustrated in Figure 1 is steadily increasing. Since demand is greater than supply in Indonesia's auditing market, accounting firms have ample opportunities to obtain new audit clients. Therefore, audit teams should be aware of extensive audit procedures in the initial audit engagement.

\section{A. Purpose of Study}

The purpose of this paper is to:

- $\quad$ Explore possible reasons for auditor switching and to analyze the main driver of auditor switching for a specific company, referred to in this study as "Superannuation 12" to protect the company's true identity,

- Understand the differences in audit procedures between an initial audit and a recurring audit. 


\section{ANALYTICAL FRAMEWORK}

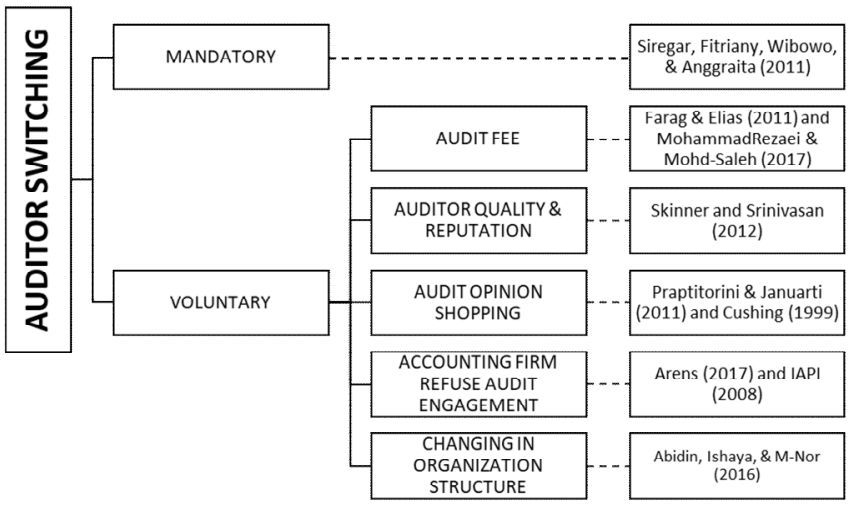

Fig. 2. Reasons for Auditor Switching

\section{A. Mandatory Auditor Switching}

Auditees are sometimes required to change their auditors by law. Indonesia's Otoritas Jasa Keuangan issued regulation No. 13 /POJK.03/2017 about utilizing services from public accountants and accounting firms in financial services activities. The regulation prohibits the same public accountant from issuing an opinion on an auditee more than three years in a row and requires a "cooling-off" period thereafter of at least two years. Benefits of this regulation are that auditees gain a fresh perspective from their new accounting firm and it prevents the risks of using the same accounting firm for too long a period. The objective of this regulation is to prevent erosion of the independence of public accountants, especially in cases where an audit uncovers any unusual accounting practices with the auditee [11].

\section{B. Voluntary Auditor Swtiching}

Aside from this mandatory reason for switching auditors, there are five reasons an auditee voluntarily changes its auditor, initiated either by the auditee itself or by another accounting firm. One reason for auditor switching is the audit fee. An auditee who paid an audit fee that is notably higher than the average for its industries tends to change its auditor, vice versa [12]. Thus, the auditor needs to be careful when increasing its fee for a subsequent audit. An increase in the number of auditors drives audit market competition that causes auditor switching to happen frequently [13].

A second reason is the quality and reputation of the auditor. Auditees who are aware of audit quality take into consideration any problems that negatively affected an accounting firm's reputation, even though there may have been no litigation involved. According to Hennes, Leone, and Miller (2011), an auditee tends to change its auditor when an auditor's quality is questioned to prevent adverse effects on its stock price [14]. However, a decision to change auditors involves switching costs. A relatively large number of auditees who are concerned with audit quality and become aware of bad publicity or suspension of an auditor will change their auditor [14]. Conversely, an auditee that is not aware of issues regarding auditor quality will tend to defend with its auditor bad publication and moved to another accounting firm because the previous one had already suspended.

The third reason for switching is known as audit opinion shopping, i.e., seeking a more favorable audit opinion by switching to a different auditor. External stakeholders often believe that an audit opinion determines the reliability of financial reports. Thus, management may try to change an auditor who is planning to give a going concern opinion or opinions other than an unqualified opinion [15]. There are two possible auditor responses in this situation. The first option is to refuse the auditee's request to change the opinion that prompted the interest in switching, i.e., to risk losing the auditee as a client, and the income from that client. Another option is to accept the auditee's request. This also has one or more adverse outcomes, including sacrificing the reliability of the client's financial reports, creating a possibility of being sanctioned by the authorities and potentially losing credibility [16].

Refusal of an audit engagement is the fourth reason for auditor switching. Auditors should refuse an auditee with higher than acceptable risks based on the accounting firm's policies. The following are some risks that may threaten an audit engagement [8;17].

- limited resources,

- significant threats that could erode the auditor's independence,

- auditee's integrity and professionalism are being questioned,

- auditee is involved in illegal activities, fraud, and/or unusual financial reporting,

- no commitment to improve governance and internal controls,

- auditee wants to limit the scope of the auditor's work,

- going concern status is being questioned.

The final reason an auditee changes its auditor is in response to changes in organizational structure. Studies show that the higher the percentage of independent (outside) directors on an auditee's board of directors, the more often the auditee changes its auditor, because independent directors' demand for improved audit quality reduces the threat of self-dealing and familiarity [18]. In addition, a change in auditee's chief executive officer is usually followed by a change in auditor.

\section{Initial Audit Procedures}

There are two types of first-year audit engagements: (1) an auditee whose previous financial statements were not audited, and (2) an auditee whose financial statements for the prior period were audited by a predecessor auditor [1-7]. This paper focuses on the second type of first-year audit engagements.

The extended audit procedures for a first-time audit are based on SA, the valid auditing standards in Indonesia issued by Institut Akuntan Publik Indonesia (IAPI) that are based on the International Standards on Auditing (ISA) issued by the International Auditing \& Assurance Standards Board. Further explanations of those procedures are available in auditing books such as [19] and Gray [20].

\section{METHOD}

This paper is a case study with the goal of finding the main driver of auditor switching for the company referred to 
in this study as Superannuation 12 (not its real name) when the auditing firm AP 111 (not its real name) was appointed as its successor auditor. For confidentiality reasons, we use fictitious names for the auditee and the auditor. As a successor auditor, this was a first-year audit engagement for AP 111, which meant it had to perform several extended audit procedures that are not required for a recurring audit. Superannuation 12 as an auditee had entrusted AP 111 to do the general audit on its financial statements and investment report as of December 31, 2017. Previously, Superannuation 12 had used another accounting firm as its external auditor.

The information in this paper is qualitative data. The method of data collection is an observational survey conducted while the author was part of the audit team that audited Superannuation 12 during the fieldwork stage, which lasted approximately two months. The author acted as participant-observer, expending significant efforts to gather the needed information. The primary data used in this paper are questionnaires that contain some of the questions that are helpful in the auditee acceptance process, letters that refer to communication with the previous auditor, and some working papers from the current period. The paper also includes secondary data from public information stated in references, such as five years of the auditee's historical annual reports.

\section{RESULT AND DISCUSSION}

\section{A. The Reason for Auditor Switching}

\section{1) Mandatory Auditor Switching}

Table I is compiled from the company's annual reports. Column (d) shows that no public accounting firm signed Superannuation 12's independent auditor report for more than two years during the period 2012 - 2017. The company used auditing services from several accounting firms over the period so there is no evidence of mandatory auditor switching.

TABLE I. HistoriCAL EXTERNAL AUDITOR AND ACCOUNTING FIRM OF SUPERANNUATION 12

\begin{tabular}{|c|c|c|c|c|c|c|}
\hline $\begin{array}{c}\text { Year } \\
\text { (a) }\end{array}$ & $\begin{array}{c}\text { Global } \\
\text { Account } \\
\text { ing } \\
\text { Firm (b) }\end{array}$ & $\begin{array}{c}\text { Local } \\
\text { Account } \\
\text { ing } \\
\text { Firm (c) }\end{array}$ & $\begin{array}{l}\text { Public } \\
\text { Account } \\
\text { ant (d) }\end{array}$ & $\begin{array}{l}\text { Audit } \\
\text { Fee* } \\
\text { (e) }\end{array}$ & $\begin{array}{c}\text { Ranki } \\
\text { ng } \\
(f)^{* *}\end{array}$ & $\begin{array}{c}\text { Audit } \\
\text { or's } \\
\text { Opini } \\
\text { on (g) }\end{array}$ \\
\hline 2012 & AP XXX & $\begin{array}{c}\text { AP X } \\
\text { and } \\
\text { Partners }\end{array}$ & $\begin{array}{l}\mathrm{xxx} \\
\text { CPA. }\end{array}$ & $\$ 12,900$ & 10 & \multirow{6}{*}{$\begin{array}{l}\text { Unmo } \\
\text { dified }\end{array}$} \\
\hline 2013 & AP YYY & $\begin{array}{c}\text { AP Y } \\
\text { and } \\
\text { Partners }\end{array}$ & $\begin{array}{l}\text { VVv, } \\
\text { CPA. }\end{array}$ & $\$ 9,300$ & $\begin{array}{c}\text { Lower } \\
\text { than } \\
\text { top } 10\end{array}$ & \\
\hline 2014 & AP ZZZ & $\begin{array}{c}\text { AP Z } \\
\text { and } \\
\text { Partner }\end{array}$ & $\begin{array}{l}\text { zZZ, } \\
\text { CPA. }\end{array}$ & $\$ 14,300$ & 8 & \\
\hline 2015 & AP ZZZ & $\begin{array}{c}\text { AP Z } \\
\text { and } \\
\text { Partner }\end{array}$ & $\begin{array}{c}\text { zzz, } \\
\text { CPA. }\end{array}$ & $\$ 14,300$ & 8 & \\
\hline 2016 & AP YYY & $\begin{array}{c}\mathrm{AP} \mathrm{Y} \text {, } \\
\mathrm{W}, \text { and } \\
\mathrm{V}\end{array}$ & $\begin{array}{l}\text { yyy, } \\
\text { CPA. }\end{array}$ & unknown & $\begin{array}{c}\text { Lower } \\
\text { than } \\
\text { top } 10\end{array}$ & \\
\hline 2017 & $\begin{array}{c}\text { AP } 111 \\
\text { Internasi } \\
\text { onal }\end{array}$ & $\begin{array}{c}\text { AP } 111 \\
\text { Indonesi } \\
\mathrm{a}\end{array}$ & $\begin{array}{l}\text { aaa, } \\
\text { CPA. }\end{array}$ & $\$ 31,400$ & 7 & \\
\hline
\end{tabular}

b. ** global accounting firm ranking in 2017 based on its revenue in worldwide c. Source: Historical Annual Report of Superannuation 12

\section{2) Voluntary Auditor Switching}

The audit fee is listed in column (e) of Table I. The audit fee in 2017 was the highest fee paid over the past six years, so we conclude that the audit fee was not the main reason for auditor switching in this case. Unfortunately, we cannot analyze this more extensively because the average audit fee in the superannuation industry is not available in Indonesia.

The reputation of each accounting firm is shown in column (f). No additional criteria are used to measure auditor reputation [14]. According to Magnis and Iatridis (2017), auditor reputation consists of two components: auditor types (Big 4 versus non-Big 4 auditors) and auditor industry specialization. The following discussion about auditor reputation is based on Magnus and Iatridis, 2017 [21].

Higher specialization is associated with Big 4 auditors, not only because they have more resources but because they are willing to devote more resources to specialized staff training, peer reviews, and information technology compared to non-Big 4 firms (Craswell et al., 1995). Also, greater independence is associated with Big 4 auditors because they have stronger reputations compared to non-Big 4 auditors. Big 4 firms are expected to have a combination of greater experience, resources, and incentives to protect their reputational capital.

Superannuation 12's management said the reason for the auditor switching was the board of directors seeking audit quality improvement, as the previous auditor did not meet their expectations. The Board of Directors of Superannuation 12 suggested changing the auditor due to the excessively long and trivial explanations provided during the closing audit meeting. Another explanation for auditor switching from is Superannuation 12's need for an accounting firm from within the top ten ranking. Explanations from both Superannuation 12 and the previous auditor support this. AP 111 ranks higher than the other accounting firms used by Superannuation 12 in the past, and AP YYY, the firm used in 2016, is not among the top ten global accounting firms. The ranking is valid globally, but the order of the ranking may be different in Indonesia. There is no negative publicity and no penalties from Pusat Pembinaan Profesi Keuangan for Superannuation 12's historical auditors and accounting firms. Based on this analysis, we conclude that the main reason for auditor switching for Superannuation 12 was reputation.

There is also no evidence of audit opinion shopping, based on the analysis of the client acceptance questionnaire prepared by the audit team. In addition, Superannuation 12 had received an unmodified opinion continuously for the previous five years. A more precise way to indicate audit opinion shopping is to predict the possible opinion if an auditee did not change its auditor but the model can only be used for a public company.

As noted previously, one of the reasons an auditee changes its accounting firm is because another accounting firm had refused the audit engagement. Based on the communication of previous auditor, there is no indication that the previous auditor refused the audit engagement.

Lastly, auditor switching can result from a change in organizational structure. All members of the board of directors are independent. In Superannuation 12's case, even though there was no change in management, the auditor is still changed multiple times over these six years. We 
conclude that a change in organization structure is not the main driver of auditor changing in this case.

TABLE II. TOP MANAGEMENT IN SUPERANNUATION 12

\begin{tabular}{|c|c|c|c|c|}
\hline Year & CEO & Directors & $\begin{array}{c}\text { Global } \\
\text { Accounting } \\
\text { Firm } \\
\end{array}$ & $\begin{array}{l}\text { Chief of } \\
\text { Trustee }\end{array}$ \\
\hline 2012 & $\begin{array}{l}\mathrm{Mr} . \\
\mathrm{AA}\end{array}$ & $\begin{array}{l}\mathrm{Mr} . \mathrm{BB} \text { and } \\
\mathrm{CC}\end{array}$ & AP XXX & Mrs. FF \\
\hline 2013 & $\begin{array}{l}\mathrm{Mr} . \\
\mathrm{AA}\end{array}$ & $\begin{array}{l}\mathrm{Mr} . \mathrm{BB} \text { and } \\
\mathrm{CC}\end{array}$ & AP YYY & Mrs. FF \\
\hline 2014 & $\begin{array}{l}\mathrm{Mr} . \\
\mathrm{AA}\end{array}$ & Mr. CC & AP ZZZ & Mrs. FF \\
\hline 2015 & $\begin{array}{l}\mathrm{Mr} . \\
\mathrm{AA}\end{array}$ & $\begin{array}{l}\text { Mr. DD and } \\
\text { EE }\end{array}$ & AP ZZZ & Mrs. GG \\
\hline 2016 & $\begin{array}{l}\mathrm{Mr} . \\
\mathrm{AA}\end{array}$ & $\begin{array}{l}\text { Mr. DD and } \\
\text { EE }\end{array}$ & AP YYY & Mrs. GG \\
\hline 2017 & $\begin{array}{l}\mathrm{Mr} . \\
\mathrm{AA}\end{array}$ & $\begin{array}{l}\text { Mr. DD and } \\
\text { EE }\end{array}$ & $\begin{array}{c}\text { AP } 111 \\
\text { International }\end{array}$ & Mrs. GG \\
\hline
\end{tabular}

\section{B. Initial Audit Procedures}

The following describes the extended audit procedures involved in a first-year audit where the financial statements for the prior period were audited by a predecessor auditor, but are not needed for a recurring audit.

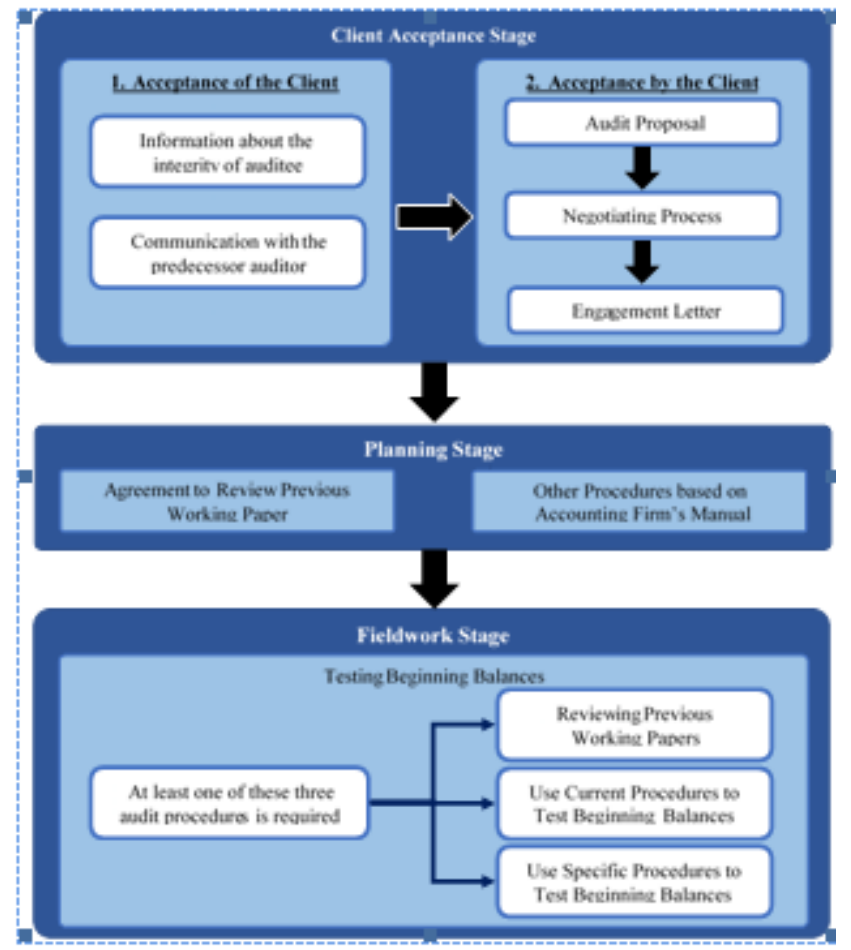

Fig. 3. Initial Audit Procedures

\section{1) Client Acceptance Stage}

The first stage of an audit engagement is called the client acceptance stage. Accounting firms have two objectives in this phase [19]. They must not only to assess the feasibility of working with the prospective auditee (acceptance of the client), but also to be chosen as the auditor (acceptance by the client).

\section{a) Acceptance of the Client}

This first stage is aimed at ensuring there is no reason to refuse the auditee, either from a risk perspective or for ethical issues. The IAPI specifies some activities to decide whether to accept the prospective auditee or not during the initial audit engagement in SA 300. Audit teams have to follow audit procedures required by SA 200 and Standar Pengendalian Mutu (SPM 1) to maintain the accounting firm's quality. Information can be gathered by communicating with previous auditor, other from reliable third parties, i.e., bankers, legal advisor, other accounting firms and colleagues in the same industry as the auditee [17]. Additional background information can be found in other sources, such as reliable mass media. If there is any problem in communicating with the previous auditor, the new auditor can assign a professional to do background checks of key management personnel of the auditee [17]. Some matters worth considering about integrity are discussed below

(a) Information about the owner, key management, and TCWG of auditee.

- reputation of the owner(s) if the company is privately or closely held, key management personnel, and TCWG of the auditee,

- the nature of the business,

- information about the behavior of owners (if the company is privately or closely held), key management, and TCWG toward the application of accounting standards and ineffective internal controls,

- $\quad$ the probability the auditee will require an audit fee that is too low,

- the reason behind auditor switching, and

- identity and reputation of related parties affiliated with auditee.

(b) Communication with The Predecessor Auditor The successor auditor has a responsibility to initiate communication with the predecessor auditor [17]. Based on [17], Standar Audit [22], and [19], this communication should be done during the client acceptance stage. SPAP 315 gives auditors more flexibility in the timing as long as the acceptance of the audit engagement is not finalized before the communication with predecessor auditor is finished. The predecessor auditor should respond to the successor auditor who has already got permission from auditee either the successor auditor will accept the audit engagement or not. Kode Etik Profesi Akuntan Publik, modified by the IAPI's Code of Ethics for Professional Accountants issued by the International Ethics Standards Board of Accountants, suggests written communication when the successor auditor asks permission from the auditee. AP 111 had just started the communication with the previous auditor by sending a letter and did not receive any response until the fieldwork stage. Unfortunately, the previous auditor was late in responding due to its workload in the peak auditing season. AP 111 had to discuss any problem arising from communication with the previous auditor with the Head of Audit and Assurance [23]. 


\section{b) Acceptance by the Client}

After ensuring that the auditee is acceptable, the next step is ensuring the auditee will choose AP 111 as its new auditor. Here are the few audit procedures in order to achieve this second objective.

\section{(a) Audit Proposal}

Even though an audit proposal is needed for both initial and recurring audits, the successor auditor should place particular emphasis on this matter. One of the contents in audit proposal is the strength of accounting firm, such as having experienced auditors and maintaining audit quality in accordance to its affiliation with an international accounting firm. It should also describe the benefits the auditee would obtain if auditee decided to switch to the new auditor.

(b) Negotiating Process

An auditor may propose a low audit fee for a prospective client as one of its strategies [1-7]. Even though it is not unethical (although it is called "low-balling"), there may be risks of doing so, such as the tendency to reduce the time spent and number of audit procedures to compensate for the low audit fee [19]. Auditors should apply some safeguards to reduce these risks to an acceptable level. Other than the audit fee mentioned above, there are two other types of fees. Contingencies fee are paid if a specific result is achieved, calculated by percentage of the result [19]. This fee is freely and widely acceptable for other professional services besides auditing. A referral fee is allowed for audit services as long as the auditee is wellinformed and willingly agrees.

\section{(c) Engagement Letter}

An engagement letter is needed for both initial and recurring audit, but there is a different section for an initial audit. There are two approaches regarding the comparative information disclosure: Corresponding Figures and Comparative Financial Statements. These approaches imply different auditor reporting responsibilities, based on the purpose of reporting comparative information and the period of written representations. The auditor shall state the type and date of prior period opinion by the predecessor auditor in an Other Matter paragraph in the current auditor's report.

TABLE III. COMPARATIVE INFORMATION APPROACHES

\begin{tabular}{|c|c|c|c|}
\hline Approaches & Auditor Opinion & $\begin{array}{c}\text { Comparative } \\
\text { Information is } \\
\text { Included }\end{array}$ & $\begin{array}{c}\text { Written } \\
\text { Representations }\end{array}$ \\
\hline $\begin{array}{c}\text { Corresponding } \\
\text { Figures }\end{array}$ & $\begin{array}{c}\text { Refers to the } \\
\text { current period } \\
\text { financial } \\
\text { statements only } \\
\text { as a whole }\end{array}$ & $\begin{array}{c}\text { as an integral } \\
\text { part of the } \\
\text { current period } \\
\text { financial } \\
\text { statements }\end{array}$ & $\begin{array}{c}\text { For current } \\
\text { period only }\end{array}$ \\
\hline $\begin{array}{c}\text { Comparative } \\
\text { Financial } \\
\text { Statements }\end{array}$ & $\begin{array}{c}\text { Refers to each } \\
\text { period presented } \\
\text { in financial } \\
\text { statements }\end{array}$ & $\begin{array}{c}\text { for comparison } \\
\text { with the financial } \\
\text { statements of the } \\
\text { current period }\end{array}$ & $\begin{array}{c}\text { For each period } \\
\text { presented in the } \\
\text { financial } \\
\text { statements }\end{array}$ \\
\hline
\end{tabular}

\section{2) Planning Stage}

a) Agreement to Review Previous Working Papers

Auditors should arrange to review previous working paper with the previous auditor. In this study, AP 111 could not do so because the previous auditor was late in providing a response before the planning stage, although the previous auditor did send a letter during the fieldwork stage.

\section{Materials}

b) Other Procedures based on Accounting Firm's

Based on AP 111's Audit Manual, the audit team should test several journal entries to detect possible fraud arising from management override of controls. Journal entries may be classified in three categories: standard (repeating, reversing), non-routine (adjustments), and unusual or management requested entries.

\section{3) Fieldwork Stage}

\section{a) Testing the Beginning Balance}

Beginning balances are not only about the amounts shown in financial statements, but also in disclosures such as commitments and contingencies. SA 510 makes it the auditor's responsibility to gather sufficient and appropriate audit evidence about beginning balances and the consistency of accounting policies. Auditors should perform one or more of the following procedures to gather such evidence:

- Review the prior period's working papers. Unfortunately, AP 111 could not do this because of the workload of the predecessor auditor.

- Evaluate whether audit procedures performed in the current period provide sufficiently evidence to support the beginning balances. AP 111 performed several current procedures that could be used to test beginning balances.

- Perform specific audit procedures to obtain evidence about beginning balances. AP 111 applied these procedures for some accounts where the prior period's disclosure was not sufficient, based on the auditor's judgment.

\section{CONCLUSION}

Based on the analysis, we conclude that the auditor switching for Superannuation 12 was voluntary. Specifically, the primary reason Superannuation 12 switched its auditor is that it was looking for an accounting firm with a stronger reputation to improve audit quality. There is no strong evidence of other voluntary auditor switching factors, such as audit opinion shopping, change in organizational structure, audit fee, or audit engagement refusal from other accounting firms.

Some extended audit procedures are needed to overcome the risks of an initial audit engagement where the financial statements for the prior period were audited by a predecessor auditor. In the client acceptance stage, the new auditor is gathering information about the prospective auditee's integrity and is communicating with the predecessor auditor, important procedures that are necessary to collect adequate information about the auditee. Before communicating with the previous auditor, the new audit team should ask permission from the client, which should be supplied in written form, allowing the previous auditor to 
share the auditee's information with the new auditor. Communicating with the predecessor auditor can be done through written or oral communication. In the Acceptance by the Client stage, the audit proposal should focus on the benefits and urgency of auditor switching, negotiating the audit fee, and creating an engagement letter focusing on the two different approaches of presenting comparative information. The different approaches will impact an auditor's responsibility in giving an opinion and the written representation period from auditee's management. In this case, AP 111 chose to use the corresponding figures approach while auditing Superannuation 12. To improve the efficiency of the initial audit engagement, auditors should divide the client acceptance stage into two parts: acceptance by the client and acceptance of the client, even though it is not obligated to do so by any auditing standard.

Extended audit procedures in the planning stage include the agreement to review the previous year's working papers and other procedures based on the accounting firm's audit manual. Extended audit procedures in the fieldwork stage include verifying beginning balances, which can be done by executing at least of one of three procedures: reviewing the previous auditor's working papers, audit procedures for the current year that also test beginning balance, and/or specific procedures to test beginning balances.

Based on this study, the author proposes that Ikatan Akuntan Publik Indonesia should not be translated from ISA directly, but should adapt necessary features from SPAP. For example, auditors should explain in the engagement letter that the engagement is not finalized until communication with the previous auditor is finished. The authorities, namely Pusat Pembinaan Profesi Keuangan (P2PK), is expected to publish audit fees so future research can better analyze audit fees as one factor behind auditor switching. Next, P2PK is expected to issue a regulation that requires the previous auditor to respond promptly in giving previous period information to a successor auditor. In this author's opinion, they should include penalties in case of late to response.

The definition of auditor reputation is one of limitations in this study. For future research it would be useful to improve the way auditor reputation is measured. Researchers could build a model to predict audit opinion for non-public companies if an auditee does not move to new auditor. Based on most of the existing literature, auditor reputation is divided into two groups: Big 4 and non-Big 4, but this is too simplistic because there are likely differences among non- Big 4 accounting firms' reputations. Future research could attempt to obtain auditor rankings in Indonesia based not only on audit fees, but on several aspects that would better reflect an auditor's reputation.

\section{REFERENCES}

[1] Dewan Standar Profesional. (n.d.). Standar audit 200: Tujuan keseluruhan auditor independen dan pelaksanaan audit berdasarkan standar audit. Jakarta: Ikatan Akuntan Publik Indonesia.

[2] Dewan Standar Profesional. (n.d.). Standar audit 220: Pengendalian mutu untuk audit atas laporan keuangan. Jakarta: Ikatan Akuntan Publik Indonesia.

[3] Dewan Standar Profesional. (n.d.). Standar audit 300: Perencanaan suatu audit atas laporan keuangan. Jakarta: Ikatan Akuntan Publik Indonesia.
[4] Dewan Standar Profesional. (n.d.). Standar audit 500: Bukti audit. Jakarta: Ikatan Akuntan Publik Indonesia.

[5] Dewan Standar Profesional. (n.d.). Standar audit 510: Perikatan audit tahun pertama-Saldo awal. Jakarta: Ikatan Akuntan Publik Indonesia.

[6] Dewan Standar Profesional. (n.d.). Standar audit 580: Representasi tertulis. Jakarta: Ikatan Akuntan Publik Indonesia.

[7] Dewan Standar Profesional. (n.d.). Standar audit 710: Informasi komparatif-Angka koresponding dan laporan keuangan komparatif. Jakarta: Ikatan Akuntan Publik Indonesia.

[8] Dewan Standar Profesional Akuntan Publik. (2008). Kode etik profesi akuntan publik. Jakarta: Ikatan Akuntan Publik Indonesia.

[9] Nadia (2013). Standar Audit Internasional (ISA) untuk Indonesia. March 30, 2018. https://feb.ugm.ac.id/id/berita/538-standar-auditinternasional-isa-untuk-indonesia

[10] Aco, Hasanudin. (2013). Indonesia Butuh 190.000 Akuntan. June 13, 2018. http://www.tribunnews.com/nasional/2013/05/31/indonesiabutuh-190000-akuntan.

[11] Siregar, Sylvia V., Fitriany, Wibowo, A., \& Anggraita, V. (2011). Rotasi dan kualitas audit: Evaluasi atas kebijakan menteri keuangan KMK no. 423/KMK.6/2002 tentang jasa akuntan publik. Jurnal Akuntansi dan Keuangan Indonesia, 8(1), 1-17.

[12] Farag, M., \& Elias, R. (2011). Relative audit fees and client loyalty in the audit market. Accounting Research Journal, 24(1), 79-93.

[13] MohammadRezaei, F., \& Mohd-Saleh, N. (2017). Auditor switching and audit fee discounting: The Iranian experience. Asian Review of Accounting, 25(3), 335-360.

[14] Skinner, D., \& Srinivasan, S. (2012). Audit quality and auditor reputation: Evidence from japan. The Accounting Review, 87(5), 1737-1765.

[15] Praptitorini, Mirna D., \& Januarti, I. (2011). Analisis pengaruh kualitas audit, debt default dan opinion shopping terhadap penerimaan opini going concern. Jurnal Akuntansi dan Keuangan Indonesia, 8(1), $1-17$.

[16] Cushing, B. (1999). Economic analysis of audit opinion shopping. Journal of Accounting and Public Policy, 18(45), 339-363.

[17] Arens, Alvin A., Elder, Randal J., Beasley, Mark S., Hogan, \& Chris E. (2017). Auditing and assurance services: An integrated approach (16th ed.). New Jersey: Pearson Prentince Hall.

[18] Abidin, S., Ishaya, I. V., \& M-Nor, M. (2016). The association between corporate governance and auditor switching decision. International Journal of Economics and Financial Issues, 6(7), 77-80.

[19] Hayes, R., Wallage, P., \& Gortemaker, H. (2014). Principles of auditing an introduction to international standards on auditing (3rd ed.). United Kingdom: Pearson Education Limited.

[20] Gray, Iain \& Manson, Stuart. (2011). The Audit Process, Principles, Practice and Cases (16th ed.). United Kingdom: South-Western CENGAGE Learning.

[21] Magnis, C., \& Iatridis, G.E. (2017). The relation between auditor reputation, earnings and capital management in the banking sector: An international investigation. Research in International Busisness and Finance, 39(A), 338-357.

[22] International Auditing and Assurance Standards Board. (n.d.). International standard on auditing 710: Comparative informationCorresponding figures and comparative financial statements. New York: International Federation of Accountants.

[23] AP 111 International. (2016). 111 audit manual 2016.1

[24] Dewan Komisioner Otoritas Jasa Keuangan. (2017). Peraturan otoritas jasa keuangan nomor 13 /POJK.03/2017 tentang penggunaan jasa akuntan publik dan kantor akuntan publik dalam kegiatan jasa keuangan. Jakarta: Otoritas Jasa Keuangan.

[25] Dewan Standar Akuntansi Keuangan. (2014). Pernyataan standar akuntansi keuangan nomor 1 revisi 2014: Penyajian laporan keuangan. Jakarta: Ikatan Akuntan Indonesia.

[26] Ikatan Akuntan Indonesia. (2001). Standar profesional akuntan publik seksi 315: Komunikasi antara auditor pendahulu dengan auditor pengganti. Jakarta: IAI.

[27] Lennox, C. (2000). Do companies successfully engage in opinion shopping: Evidence from the UK?. Journal of Accounting and Economics, 29(3), 321-337.

[28] Saham OK (n.d.). Emiten. June 13, 2018. https://www.sahamok.com/ emiten/ 
[29] The CA magazine (2017, December 5). The top 30 accountancy firms for 2017 revealed. April 9, 2018. https://www.icas.com/ca-todaynews/the-top-30-accountancy-firms-in-2017-revealed

[30] Tuanakotta, Theodorus M. (2015). Audit Kontemporer. Jakarta: Penerbit Salemba Empat.

[31] Pusat Pembinaan Profesi Keuangan (2018). Daftar akuntan publik (AP) yang dikenakan sanksi pembekuan izin. April 23, 2018. http://pppk.kemenkeu.go.id/Publikasi/Details/50
[32] Pusat Pembinaan Profesi Keuangan (2018). Daftar akuntan publik (AP) yang sudah tidak aktif. April 23, 2018. http://pppk.kemenkeu. go.id/Publikasi/Details/48

[33] Pusat Pembinaan Profesi Keuangan (2018). Daftar kantor akuntan publik (KAP) yang sudah tidak aktif. April 23, 2018. http://pppk.kemenkeu.go.id/Publikasi/Details/49 